\title{
Langerhans Cell Histiocytosis: Excellent Local Control with Low Dose Radiotherapy
}

\author{
Serra Arun KAMER ${ }^{1}$, Esra Korkmaz KIRAKLI², Nazan CETINGUL ${ }^{3}$, Mehmet KANTAR ${ }^{3}$, \\ Guray SAYDAM ${ }^{4}$, Yavuz ANACAK ${ }^{1}$ \\ ${ }^{1}$ Ege University, Faculty of Medicine, Department of Radiation Oncology \\ ${ }^{2}$ Dr Suat Seren Chest Diseases and Surgery Training Hospital, Department of Radiation Oncology \\ ${ }^{3}$ Ege University, Faculty of Medicine, Department of Pediatric Oncology \\ ${ }^{4}$ Ege University, Faculty of Medicine Department of Hematology, İzmir, TURKEY
}

\begin{abstract}
Langerhans cell histiocytosis $(\mathrm{LCH})$ is a rare disorder. Uncontrolled clonal proliferation of langerhans cells leads to a diversity of clinical manifestations. Low dose Radiotherapy (RT) is used mainly for osseous manifestations as a sole treatment or in combination with surgery/chemotherapy/steroids. Altough the mechanism of action of RT is an unresolved issue, it's usually used in adjuvant/palliative settings, also as first-line local therapy with curative intent in unresectable or resectable cases in case surgery would result in functional compromise. This study is conducted to review indications, dose-fractionation schedules, clinical characteristics and outcomes of LCH patients received local RT mainly for osseous lesions. The medical records of biopsy proven all LCH patients referred to our center and treated with RT between 2000-2016 were evaluated retrospectively. Disease-free survival (DFS), local control and side effects were defined as study end-points. There was 35 patients, 21 of them were children. At presentation $65.7 \%$ had single systemsingle bone, $20 \%$ had single system-multiple bone, $15 \%$ had multisystem disease.Soft tissue extension were detected in 16 children, 4 adults ( $p=0.013)$. Mean radiation dose was $10.8 \mathrm{~Gy}$. Median follow-up from the date of biopsy was 105 months (range= 8-204) in children and 88 (range:31-245) in adults (log rank p:0.029).Complete response rate was 97\%. 11 children and 1 adult experienced relapse $(p=0.05)$, median interval for relapse was 9 months in children, 19months in adults. The most common relapse pattern was as single system-multiple bone (58.3\%). Local control was $97.1 \%$. Median disease free survival was 85 months. Low dose local RT seems to be effective and safe in multidisciplinary management of $\mathrm{LCH}$.
\end{abstract}

Keywords: Langerhans cell histiocytosis, Radiotherapy, Local control

ÖZET

\section{Langerhan Hücreli Histiositozis: Düşük Doz Radyoterapi ile Mükemmel Lokal Kontrol}

Langerhans hücreli histiositozis $(\mathrm{LCH})$, langerhans hücrelerine benzer dentritik hücrelerin çeşitli organlarda birikimi ve kontrolsüz klonal çoğalması ile karakterize, nadir görülen bir hastalıktır. Düşük doz radyoterapi (RT) ağrılı ve stabil olmayan kemik lezyonları ve kemik dışı yumuşak doku lezyonlarının tedavisinde tek başına ve/veya cerrahi, kemoterapi, steroidlerle birlikte kullanılmaktadır. Etki mekanizması halen net olarak anlaşılmamıştır. RT genelde adjuvant ve palyatif endikasyonlarda, ayrıca rezeke edilemeyen veya cerrahinin fonksiyonel hasar yaratabileceği rezektable olgularda küratif amaçlı olarak kullanılmaktadır. Bu çalışmada, çoğunlukla kemik lezyonlarına yönelik lokal RT uygulanan LCH tanılı olgularda klinik özellikler, RT endikasyonları, doz-fraksiyonizasyon şemaları ve tedavi sonuçlarının araştıııması amaçlanmışıı. 2000-2016 tarihlerinde kliniğimizde RT uygulanan biopsi ile kanıtlanmış tüm LCH tanılı olguların tedavi ve izlem kayıtları geriye dönük olarak değerlendirilmiştir. Hastalıksız sağkalım, lokal kontrol ve geç yan etki çalışmanın sonlanım noktaları olarak belirlenmiştir. 35 olgu saptanmıştır. Ortanca yașı 12 (6-27), 21 olgu (\%60) pediatrik yaş grubundadır. Olguların \%65.7'sinde tek sistem-tek kemik tutulumu, \%20'sinde tek sistem-çoklu kemik tutulumu, \%15'inde çoklu sistem tutulumu saptanmıştır. Pediatrik yaş grubundaki olguların 16'sında ve erişkinlerin 4'ünde kemik lezyonlarına yumuşak doku uzanımının eșlik ettiği tespit edilmiştir ( $p=0.013)$. Ortanca RT dozu10,8 Gy'dir. Patolojik tanı tarihinden itibaren olan ortanca izlem süresi pediatrik olgularda 105 (18-195), erişkinlerde 88 (31-245) aydır. Tam yanıt oranı \%97'dir. İzlemde 11 pediatrik, 1 erişkin olguda yineleme saptanmıştı $(p=0.05)$, yineleme için geçen ortanca süre pediatrik olgularda 9ay, erişkin olguda 19aydır.Ortanca hastalıksız sağkalım 85 ay (52-117) olarak tespit edilmiş̧ir. En sık yineleme paterni tek sistem-çoklu kemik tutulumu olarak izlenmiştir.Lokal control \%97.1'dir. Ortanca hastalıksız sağkalım 85 aydır. LCH'de düşük dozda RT multidisipliner tedavinin bir parçası olarak, etkin lokal kontrol sağlayabilen, güvenilir bir tedavi seçeneğidir.

Anahtar Kelimeler: Langerhans hücreli histiositozis, Radyoterapi, Lokal kontrol

ORCIDs: Serra KAMER: $\quad$ 0000-0001-8316-9976 Yoldas KANTAR: 0000-0002-0581-1166
Esra Korkmaz KIRAKLI: 0000-0003-4557-2865 Güray SAYDAM:
0000-0001-8646-1673
Nazan CETINGUL: 0000-0002-3728-425X Yavuz ANACAK: $\quad$ 0000-0002-2548-1109 


\section{INTRODUCTION}

Langerhans cell histiocytosis $(\mathrm{LCH})$ is a rare disorder of langerhans cells which belong to mononuclear-phagocytic system. Uncontrolled clonal proliferation and accumulation of langerhans cells in different organs leads to diversity of symptoms and heterogenity of the disease. ${ }^{1-6}$ Because of this extreme clinical heterogenity, $\mathrm{LCH}$ was named previously considered as different entities such as Letterer-Siwe disease, Hand-Schüller-Christian syndrome, and eosinophilic granüloma. In 1953 Lichtensein showed histiocytic accumulation in the lesions and proposed the name 'histiocytosis X' for the disease. Since Nezelof et al. showed the accumulating histiocytes had similar phenotype with the Langerhans cells of the dermis and specifically having the unique intracytoplasmic 'Birbeck's granula', the disease termed as 'Langerhans cell histiocytosis' thereafter. ${ }^{7}$ There has been many progresses in characterization and management of LCH since then, but its nature and biology is still less understood. ${ }^{1,3-6,8-14}$

LCH can be diagnosed at any age but it is mainly a childhood disease and its incidence is around 3-5 cases per million children. ${ }^{6,-10,13,15}$ Due to rarity of the disease, the incidence in adults ( 1 to 2 per milion) may be underestimated and should be revealed. ${ }^{4,13,16,17}$

Clinical findings at representation have a broad spectrum, ranging from single bone lesion resolving spontaneously to life treatening multisystemic involvement if not treated effectively. Since LCH represents a heterogenous group of patients with respect to disease severity and outcome, treatment options are extremely variable ranging from 'wait and watch' policy to hematopoietic stem cell transplantation which should be stratified individually and risk-tailored. ${ }^{5,6,13}$

Single system disease is the most common clinical presentation with unifocal or multifocal bony lesions in $60 \%$ of cases. ${ }^{1-3,8,10}$ These lesions can be treated with surgery, radiotherapy or chemotherapy alone. Low dose RT is used in treatment of LCH mainly for osseous manifestations as a sole treatment or in combination with surgery or chemotherapy or steroids.
This study is conducted to evaluate clinical characteristics, indications, dose-fractionation schedules and outcome of $\mathrm{LCH}$ patients who received local radiotherapy mainly for osseous lesions as a component of multidisiplinary management.

\section{PATIENTS AND METHODS}

LCH patients whom were treated with radiotherapy between 2000 and 2016 referred to our center from 3 different closely cooperating centers were evaluated in terms of clinical characteristics, treatment and follow-up data retrospectively. At the time of diagnosis; the patients were clinicallly classified as single system single bone disease if only unifocal bone involvement, or single system multiple bone disease if multifocal bone involvement or multisystem disease if two or more organs/systems involved. Life treathing organs were defined as bone marrow, liver or spleen. ${ }^{18}$ Hipothalamic-pituitary axis involvement was defined as pituitary stalk thickening according to MRI findings. ${ }^{19}$

Clinical target volume (CTV) was defined as $1 \mathrm{~cm}$ margin around the tumor depending on type of radiation source used and location of the lesion. Planning target volume (PTV) was defined according immobilisation modalities and ranged between 3 to $10 \mathrm{~mm}$.

RT induced radiological response was accepted as 'complete response' if there was a complete radiological dissaperance of the irradiated lesion, "no response' in case of absence of any radiological response and partial remission if the response was in between.

RT related side effects were scored according to EORTC/RTOG toxicity scoring system. ${ }^{20}$

Relapse was defined as the radiologic evidence of a new lesion or the reappearance of previously treated lesion. DFS was calculated from the last day of radiotherapy to the relapse time.

\section{Statistical Analysis}

Continious data were expressed as mean (SD) when normally distributed and compared with Student's t-test and median (25th-75th percentiles) when skewed distributed and compared wirh Mann 
Table 1. Clinical Characteristics of pediatric and adult patients

\begin{tabular}{|llll}
\hline & Pediatric (0-16y) & Adult (16-63y) & p \\
\hline $\mathrm{n}$ & 21 & 14 & $\mathrm{NS}$ \\
Female/male ratio & $1: 2$ & $1: 1.8$ & $\mathrm{NS}$ \\
Age at diagnosis & $8(3-11)$ & $30(25-43)$ & $\mathrm{NS}$ \\
Symptom duration before diagnosis & $2(1-3)$ & $2(0-3)$ & $\mathrm{NS}$ \\
Single system, $\mathrm{n}(\%)$ & $18(85.7 \%)$ & $12(85.7 \%)$ & $\mathrm{NS}$ \\
Multisystem, $\mathrm{n}(\%)$ & $3(14.2 \%)$ & $2(14.2 \%)$ & 0.013 \\
Soft tissue component, $\mathrm{n}(\%)$ & $16(76 \%)$ & $4(28.5 \%)$ & $\mathrm{NS}$ \\
Organ dysfunction, $\mathrm{n}(\%)$ & $2(9.5 \%)$ & 0 & $\mathrm{NS}$ \\
Systemic CT, $\mathrm{n}(\%)$ & $14(70 \%)$ & $3(21.4 \%)$ & \\
\hline
\end{tabular}

Whitney U test. Normality was evaluated with Shapiro Wilk test. Categorical data were expressed as numbers (\%) and compared with Fisher's exact test. Time to event analysis was performed by Kaplan Meier method and comparisons were done by $\log$ rank test. A two sided $\mathrm{p}$ value of lower than 0.05 was considered as significant.

\section{RESULTS}

Between 2000-2016, 35 patients were treated with RT. 21 out of $35(60 \%)$ were children. Median age at diagnosis was 8 (3-11) in children and 30 (2543) in adults; female to male ratio was $1 / 2$ among children and 1/1.8 among adults. All patients were classified according to complete medical history, physical examination, laboratory tests (complete blood cell count, liver function tests, renal function tests) and bone survey (the classical bone survey was conducted for 12 patients, the others went through bone scan). Bone marrow aspiration and biopsy was performed in 25 out of 35 . The duration of symptom before diagnosis was 2 months and the main complaint was pain (91.4\% of patients).

At the time of diagnosis, biopsy was performed in 23 patients, curettage was performed in 9 patients, vertebral excision and extended tumoral surgery were performed in 2 patients.

All patients except one had a histologic diagnosis of $\mathrm{LCH}$, additionally $63 \%$ had confirmation with CD1a and S-100 positivity. Langerin (CD207) had never been tested.
At presentation $65.7 \%$ of patients (23/35) had single system single bone disease, 20\% (7/35) had single system multiple bone disease, and 5 patients ( 3 children and 2 adults) presented with multisystem disease. Bone was the most frequently involved system, and the skull was the most common site $(28.8 \%)$. At the time of diagnosis, craniofacial bone involvement was more often in pediatric cases than adults ( $42.8 \%$ vs $28.5 \%$, p:NS). Multiple bone involement rates were $6 / 21(28.5 \%)$ and $3 / 14$ (21.4\%) (p:NS) in pediatric and in adults respectively. Three or more bony sites were involved in 4/21 (19.1\%) pediatric and 2/14 (14.2\%) (p:NS) in adult patients. Soft tissue involvement accompanying bony lesions were detected in 16 children $(76 \%)$ and in 4 adults $(28.5 \%)(\mathrm{p}=0.013)$. The distribution of patients with organ involvement other than bone was as follows: skin 2, mucocutaneous 2 , lymph node 3 , lung 2 , brain (hipothalamo-pituitary axis) 2 , ears 3 , oral cavity 2 . Life treathing organ (bone marrow, liver or spleen) involvement was not present in any patients (Table 1).

At the time of diagnosis diabetes insipidus (DI) was diagnosed in 2 children with hipothalamic-pituitary axis involvement which was confirmed by MRI findings (pituitary stalk thickening).

Patients were treated with 6-10MV X-ray or electrons using a lineer accelerator. 3D conformal radiotherapy planning was used in all patients. A total of 46 lesions were irradiated in 35 patients. In children RT was used as a single modality in 22 and as adjuvant in 5 of the courses, in adults used as a single modality in 11 , as adjuvant in 7 patients, ad 


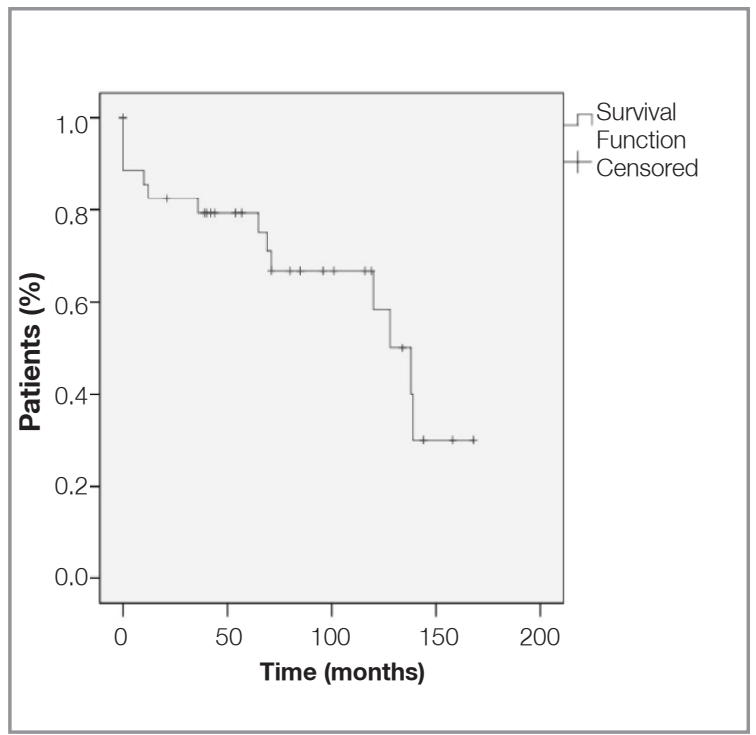

Figure 1. Disease free survival graphic in all patients

re-irradiation was performed in one patient. Cranium (28\%) was the most commonly irradiated bony site followed by femur (26\%) and vertebra (20\%). Median radiation dose was 10.8 Gy (10-10.8 Gy) in children and $11.4 \mathrm{~Gy}(10-12 \mathrm{~Gy})$ in adults with daily fractions of 1.8-2 Gy. Systemic chemotherapy (CT) was given in 70\% (14/21) of children, and $20 \%(3 / 14)$ of adults. Vinblastine+steroids was the most common regimen used as systemic treatment (9/17).

Overall median follow-up from the date of biopsy was 105 months (8-204) in children and 88 months (31-245) in adults (log rank $\mathrm{p}=0.029)$. RT induced radiological complete response was present in 31 out of 35 patients $(88.5 \%)$, partial remission in 3 $(8.5 \%)$ and no response in 1 patient, resulting a total response rate of $97 \%$. The period between RT and radiologic response was median 1 (range= 1-2) month in children and it was 4 (1-7) months in adults.

During follow-up $52.3 \%$ (11/21) of children and $7 \%(1 / 14)$ of adults experienced relapse $(\mathrm{p}=0.05)$. Median interval for relapse was 9 months in children and 19 months in adults. The most common $(58.3 \%)$ relapse pattern was single system-multiple bone disease. Only 1 adult patient developed an infield recurrence and was re-irradiated to mandible. Absolute local control rate was $97.1 \%$.
Median DFS was 85 months (95\% CI: $52-117$ ) (Figure 1), it was 71 months (95\% CI: 0-144) in children and was 85 months (95\% CI: 67-102) in adults (log rank $\mathrm{p}=0.52)$.

There wasn't any relationship between presence of soft tissue extension of bone lesion and prognosis.

Radiotherapy was well tolerated without any grade 2-4 acute side effects. Only one patient with "neurodegenerative central nervous system $\mathrm{LCH}$ " had growth retardation which was detected at the time of diagnosis and she has been on hormon replacement so far. No secondary cancers or treatment related serious late effects were developed so far.

\section{DISCUSSION}

In this study we observed high complete response and long term local control with low dose radiotherapy in LCH which can be regarded as an excellent outcome. Our results are in corcordance with the literature data reporting $73-96 \%$ local control and $60-93 \%$ complete response rates. ${ }^{1,8-10,17,21-27}$

In general, RT is usually indicated as adjuvant therapy after large, marginal or incomplete resection, as palliative therapy for painfull or unstable bony lesions, relapsing or progressing lesions, also as first-line local therapy with curative intent in unresectable cases and in unresectable cases if surgery would result in functional compromise. ${ }^{1,8,23,28-30} \mathrm{The}$ mechanism of action of RT is an unresolved issue, but suppression of inflammatory process by radiation and radiosensitivity of langerhans cells could be the main explanations. ${ }^{1,8,17,28}$ Also the questions concerning the indication, fractionation, total dose, timing and integration of RT into the whole treatment schedule remain unanswered. ${ }^{8}$

As expected the single system disease was the most common presentation, pain was the main symptom and the skull bones was the most frequent site of involvement. ${ }^{8,17,1,3,31}$

There were relapses which can be also called as 'reactivation' as proposed by Ladisch $(1982)^{13,32}$, in one third of our patients which is a similar finding with literature. ${ }^{32}$ The most common relapsing pattern was as single system-multiple bone disease and was mostly limited to the bone which is the 
same system mostly involved at presentation as stated in previous studies. ${ }^{32}$ All of the recurrences were in the first 2 years as reported in literature. ${ }^{15,33}$

Previous studies on LCH have shown that children do worse than adults. ${ }^{3,4,34}$ Similarly we have found that children relapsed more frequently than adults. This could be as a result of higher rates of multiple bone involvement at the time of diagnosis in children. Similarly three or more bony sites were involved more often in pediatric patients which is also designated as a poor prognostic factor in literature suggesting further disease progression. ${ }^{3,8,10}$ To our knowledge soft tissue component accompanying bone disease although a common clinical finding has not been previously reported as a prognostic factor in $\mathrm{LCH}$ so far. Although there was a striking difference between children and adults in terms of having soft tissue component, there was no any relationship between presence of soft tissue extension and prognosis in our findings also.

Pediatric patients received systemic chemotherapy more often than adults which is a consequence of i) having more often multifocal bone disease especially involving cranio-facial region which is a risky site for development of permanent sequela in case of disease progression and ii) having more often reactivations than adult patients.

Excellent local control and survival results found in this study could be a result of two main factors. i) the majority of our patients was presented as single system-single bone involvement which is a group of having best prognosis with minimal or no risk for life as stated in the literature. , $5,8-11,24,26,29,30,32^{-1}$ ii) in multysistem disease, the prognosis for mortality is mainly determined by the presence of risk organ involvement and risk organs are determined

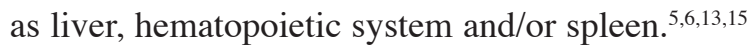
Since none of our patient cohort with multisystem disease had risk organs involved this factor also has major contribution to our fairly well outcome.

DI prevalence has very broad range in various studies, changing between 5\%-50\%, pointing out the risk of progressive disease. ${ }^{3}$ In our study, DI was present in two children $(9.5 \%)$ at the time of diagnosis. Both of these children had relapses as multisystemic in their disease courses, even one of them had twice confirming the literature in terms of higher progression risk in these gorup of patients 3 .

The RT dose and fractionation schedule in our study was uniform and close to the lower radiation dose limits reported in literatüre, where dosefractionation varies from single fraction $(0.5-6 \mathrm{~Gy}$ $\mathrm{x} 1$ fraction) to multiple fractions ( $1.8 \mathrm{~Gy}$ x 28 fractions). ${ }^{1,8,15,17,31,35-38}$ In literature, also the dose recommendations are differentiated according to age offering higher doses for adults (10-50.4 Gy) than children (6-7.5 Gy) derived by higher relapse rate in adults with lower doses. ${ }^{1,8,15,16,29}$ We applied almost the same dose schedule to both children and adults with equal results of excellent local control in both groups, concluding that higher doses may not be necessary in adult age group.

As a side effect, growth retardation (GR) was detected in a child who had neurodegenerative CNS $\mathrm{LCH}$ at the time of diagnosis and was irradiated for pontine involvement in her second relapse. Since growth hormon $(\mathrm{GH})$ deficiency is reported in literature with hipothalamic doses as low as 5 Gy, this effect in our patient could be a true cause of scattered radiation to hypothalamus but it's rather attributed to disease itself. ${ }^{15,39,40}$ The side effect incidence in this study is very low and can be explained by the low dose irradiation applied, rather than being retrospective study having limited documentation in nature. In literature, late side effect documentation is lacking making a comparison impossible but our finding is similar with data reported by Olschewski et al. (3.3\%) which is the only data as far as we know. ${ }^{17}$

Although total radiation dose in this study is relatively low, there may be a small risk for developing secondary cancers that could emerge in irradiated fields after low dose radiation in long term. Also it's known that LCH patients have higher tendency for developing malignancies irrespective of therapy. ${ }^{1}$ Greenberger et al. reported a rate of 3.9\% for the induction of malignant tumors. ${ }^{28}$ Therefore indications for radiotherapy should be dealed cautiously and limited to specific indications especially in children for such a disease which is non-malignant. ${ }^{5,15}$ Fortunately the radiotherapy indications in LCH has steadily declined because of effective alternative treatments and concerns about late effects in childrens. ${ }^{31,40}$ But our patient data has higher 
children patients than adults which can make one to concern about the carelessness on this subject. This might be the reflection of considering the risk of the higher morbidity of surgical intervention in pediatric cases.

This study has some limitations, being retrospective in nature is the main one and the small sample size is the second. Because of the low incidence of the disease, the literature covering this topic is very limited in number, mostly retrospectively designed and small sample sized also. ${ }^{5}$ Although the cases treated and observed over a period exceeding 10 years, decision making and treating radiotherapists were the same and all patients received 3D-conformal radiotherapy during this period if one concerns about the potential biases in patient selection and management of RT in such a long time period. Also we couldn't be able to give overall survival rates because there has not been any event of death yet. Our cohort sample may not be representing real charecteristics of the disease, because we only evaluated a group of LCH patients who received $\mathrm{RT}$ in their course of illness.

In a disease with such a very low incidence, carefully designed international RT trials are needed to answer the open questions about LCH. Because of extreme clinical diversity and course of the disease, tailored therapy according to patient stratification will be major concern in upcoming years.

\section{Conclusion}

Despite the low total number of patients, this study underlines the effectiveness and safety of low dose local irradition in the multidisciplinary management of LCH .

\section{REFERENCES}

1. Kriz J, Eich HT, Bruns F, et al. Radiotherapy in langerhans cell histiocytosis - a rare indication in a rare disease. Radiat Oncol 8: 233, 2013.

2. Titgemeyer $\mathrm{C}$, Grois N, Minkov M, et al. Pattern and course of single-system disease in Langerhans cell histiocytosis data from the DAL-HX 83- and 90-study. Med Pediatr Oncol 37: 108-114, 2001.

3. Kilpatrick S E, Wenger D E, Gilchrist GS, et al. Langerhans Cell Histiocytosis (Histiocytosis-X) of Bone - a Clinicopatho- logical Analysis of 263 Pediatric and Adult Cases. Cancer 76: 2471-2484, 1995.

4. Lian C, Lu Y, Shen S. Langerhans cell histiocytosis in adults: a case report and review of the literature. Oncotarget 7 : 18678-18683, 2016.

5. Hutter $\mathrm{C}$ and Minkov M. Insights into the pathogenesis of Langerhans cell histiocytosis: the development of targeted therapies. Immunotargets Ther 5: 81-91, 2016.

6. Minkov M. Multisystem Langerhans cell histiocytosis in children: current treatment and future directions. Paediatr Drugs 13: 75-86, 2011.

7. Minkov M, Grois N, Heitger A, et al. Treatment of multisystem Langerhans cell histiocytosis. Results of the DAL-HX 83 and DAL-HX 90 studies. DAL-HX Study Group. Klin Padiatr 212: 139-144, 2000.

8. Olschewski $\mathrm{T}$ and Seegenschmiedt $\mathrm{MH}$. Radiotherapy for bony manifestations of Langerhans cell histiocytosis - Review and proposal for an international registry. Strahlentherapie Und Onkologie 182: 72-79, 2006.

9. Baumgartner I, von Hochstetter A, Baumert B, et al. Langerhans'-cell histiocytosis in adults. Med Pediatr Oncol 28: 9-14, 1997.

10. Howarth D M, Gilchrist G S, Mullan B P et al. Langerhans cell histiocytosis: diagnosis, natural history, management, and outcome. Cancer 85: 2278-2290, 1999.

11. Lieberman $P H$, Jones $C$ R, Steinman RM, et al. Langerhans cell (eosinophilic) granulomatosis. A clinicopathologic study encompassing 50 years. Am J Surg Pathol 20: 519-552, 1996.

12. Willman C L, Busque L, Griffith BB, et al. Langerhans'-cell histiocytosis (histiocytosis X)--a clonal proliferative disease. N Engl J Med 331: 154-60, 1994.

13. Berres M L, Merad M, Allen CE. Progress in understanding the pathogenesis of Langerhans cell histiocytosis: back to Histiocytosis X? Br J Haematol 169: 3-13, 2015.

14. Braier J. Is Langerhans cell histiocytosis a neoplasia? Pediatr Blood Cancer 64:e26267, 2017.

15. Allen C E, Ladisch S, and McClain K L. How I treat Langerhans cell histiocytosis. Blood 126: 26-35, 2015.

16. Winkfield KM, Bazan JG, Eng TY, et al. Benign Diseases. In: Principles and Practice of Radiation Oncology. Halperin EC, Wazer DE, Perez CA, Brady LW (eds). 6 th edition. Lippincott Williams and Wilkins, a Wolters Kluwer, Philedelphia, 2013: 1729-1751.

17. Olschewski T, Seegenschmiedt MH. Radiotherapy of Langerhans' cell histiocytosis - Results and implications of a national patterns-of-care study. Strahlentherapie Und Onkologie 182: 629-634, 2006.

18. Broadbent $\mathrm{V}$ and Gadner $\mathrm{H}$. Current therapy for Langerhans cell histiocytosis. Hematol Oncol Clin North Am 12: 327-338, 1998. 
19. Robison NJ, Prabhu SP, Sun P, et al. Predictors of neoplastic disease in children with isolated pituitary stalk thickening. Pediatr Blood Cancer 60: 1630-1635, 2013.

20. Cox J D, Stetz J, and Pajak TF. Toxicity criteria of the Radiation Therapy Oncology Group (RTOG) and the European Organization for Research and Treatment of Cancer (EORTC). Int J Radiat Oncol Biol Phys 31: 1341-1346, 1995.

21. Braier J, Chantada G, Rosso D, et al. Langerhans cell histiocytosis: retrospective evaluation of 123 patients at a single institution. Pediatr Hematol Oncol 16: 377-385, 1999.

22. Egeler RM, de Kraker J, Voute PA. Langerhans-cell histiocytosis (histiocytosis X); 20-year experience in the Emma Kinderziekenhuis, 1969-1988. Ned Tijdschr Geneeskd 137 955-960, 1993.

23. Greenberger JS, Crocker AC, Vawter G, et al. Results of treatment of 127 patients with systemic histiocytosis. Medicine (Baltimore) 60: 311-338, 1981

24. Ladisch S. Langerhans cell histiocytosis. Curr Opin Hematol 5: 54-58, 1998

25. Raney RB Jr, D’Angio GJ. Langerhans' cell histiocytosis (histiocytosis X): experience at the Children's Hospital of Philadelphia, 1970-1984. Med Pediatr Oncol 17: 20-28, 1989.

26. Sessa S, Sommelet D, Lascombes P, Prevot J. Treatment of Langerhans-cell histiocytosis in children. Experience at the Children's Hospital of Nancy. J Bone Joint Surg Am 76: 1513-1525, 1994

27. Willis $B, A$ Ablin $A$, Weinberg $V$, et al. Disease course and late sequelae of Langerhans' cell histiocytosis: 25-year experience at the University of California, San Francisco. J Clin Oncol 14: 2073-2082, 1996.

28. Greenberger J S, Cassady J R, Jaffe $\mathrm{N}$ et al. Radiation therapy in patients with histiocytosis: management of diabetes insipidus and bone lesions. Int J Radiat Oncol Biol Phys 5: 1749-1755, 1979

29. Cassady J R. Current role of radiation therapy in the management of histiocytosis-X. Hematol Oncol Clin North Am 1 123-129, 1987

30. Ladisch S and Gadner H. Treatment of Langerhans cell histiocytosis--evolution and current approaches. Br J Cancer Suppl 23: S41-46, 1994

31. Winkfield KM, Gibbs IC, Eng TY, et al. Nonmalignant Diseases. In: Principles and Practice of Radiation Oncology. Halperin E C, Wazer D E, Perez C A, Brady L W (eds). 6th edition. Wolters Kluver Lippincott Williams \& Wilkins, Philedelphia, 2013: 1729-1752

32. Arico M. Langerhans cell histiocytosis in children: from the bench to bedside for an updated therapy. $\mathrm{Br} \mathrm{J}$ Haematol 173: 663-670, 2016

33. Gadner H, Minkov M, Grois $\mathrm{N}$ et al. Therapy prolongation improves outcome in multisystem Langerhans cell histiocytosis. Blood 121: 5006-5014, 2013.
34. A multicentre retrospective survey of Langerhans' cell histiocytosis: 348 cases observed between 1983 and 1993. The French Langerhans' Cell Histiocytosis Study Group. Arch Dis Child 75: 17-24, 1996.

35. Ardekian L, Peled M, Rosen D, et al. Clinical and radiographic features of eosinophilic granuloma in the jaws: review of 41 lesions treated by surgery and low-dose radiotherapy. Oral Surg Oral Med Oral Pathol Oral Radiol Endod 87: 238-242, 1999.

36. Nauert C, Zornoza J, Ayala A, Harle TS. Eosinophilic granuloma of bone: diagnosis and management. Skeletal Radiol 10: 227-235, 1983.

37. Rawlings $\mathrm{C}$ E, 3rd and Wilkins R H. Solitary eosinophilic granuloma of the skull. Neurosurgery 15: 155-161, 1984.

38. Selch MT, Parker RG. Radiation therapy in the management of Langerhans cell histiocytosis. Med Pediatr Oncol 18: $97-$ 102, 1990.

39. Merchant T E, Rose SR, Bosley C, et al. Growth hormone secretion after conformal radiation therapy in pediatric patients with localized brain tumors. J Clin Oncol 29: 4776-4780, 2011.

40. MacDonald S M. Central nervous system tumors in children. In: Clinical Radiation Oncology. Gunderson L, Tepper JE (eds). 4th edition. Elsevier, Philedelphia, 2016: 1389-1402.

\section{Correspondence:}

Dr. Esra Korkmaz KIRAKLI

Dr. Suat Seren Gogus Hastaliklari ve Cerrahisi

Egitim Hastanesi, Radyasyon Onkolojisi Bolumu

Gaziler Cad. 35210

Yenisehir IZMIR / TURKEY

Tel: (+90-232) 4572525

e-mail: esrakirakli@gmail.com 